Volume 10 Issue 1, January-March 2016: pp. 1-220. Copyright (c) 2015-2016 FIAT JUSTISIA. Faculty of Law, Lampung University, Bandarlampung, Lampung, Indonesia. ISSN: 1978-5186 | e-ISSN: 2477-6238.

Open Access: http://jurnal.fh.unila.ac.id/index.php/fiat

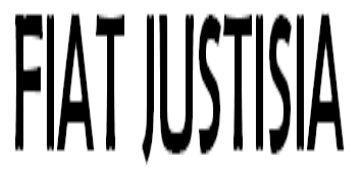

Fiat Justisia is licensed under a Creative Commons Attribution 4.0 International License, which permits unrestricted use, distribution, and reproduction in any medium, provided the original work is properly cited.

\title{
FUNGSI POLISI PAMONG PRAJA DALAM PENEGAKAN PERATURAN DAERAH (Studi Penertiban PKL Di Bandar Lampung)
}

\section{Municipal Police Functions in the Enforcement of Local Regulations (Study on Street Vendors Control in the Bandar Lampung City)}

\author{
Herni Susiani \\ Polisi Pamong Praja Provinsi Lampung \\ email: herni.susiyani@gmail.com
}

\begin{abstract}
Sometimes Municipal Police acts reactively or repressively without heed to civil rights in doing their operation. Then, Bandar Lampung government has to provide a proper place for street vendors as per local Regulation (The Law Number 8 of 2009). In order to prevent any clashes between civil service police and people in society, especially street vendors, there are several things which need to be done: (1) quality of human resource in municipal police unit need to be improved; (2) Municipal Police need to use persuasive approach in performing their job; (3) local regulation needs to be aligned; (4) local regulation has to be enforced continuously and appropriately.
\end{abstract}

Keywords: Civil Service Police Function, Local Regulation Enforcement

\begin{abstract}
Abstrak
Terkadang layanan polisi pamong praja bertindak reaktif atau represif tanpa mengindahkan hak-hak sipil dalam melakukan operasi mereka. Kemudian, pemerintah Bandar Lampung harus menyediakan tempat yang tepat untuk PKL sesuai Peraturan daerah (Undang-undang Nomor 8 Tahun 2009). Dalam rangka untuk mencegah bentrokan antara polisi pamong praja dan orang-orang di masyarakat, pedagang kaki lima terutama jalan, ada beberapa hal yang perlu dilakukan: (1) kualitas sumber daya manusia di Satuan Polisi Pamong Praja perlu ditingkatkan; (2) Polisi Pamong Praja perlu menggunakan pendekatan persuasif dalam melakukan pekerjaan mereka; (3)
\end{abstract}


peraturan daerah perlu selaras; (4) Peraturan Daerah harus ditegakkan secara terus menerus dan tepat.

\section{Kata Kunci: Fungsi Polisi Pamong Praja, Penegakan Peraturan Daerah}

\section{A. Pendahuluan}

Negara pada hakekatnya adalah suatu organisasi kekuasaan yang diciptakan oleh sekelompok manusia yang disebut bangsa. Penyebab atau faktor pertama terjadinya Negara adalah adanya sekelompok manusia yang disebut bangsa yang berkesadaran untuk mendirikan suatu organisasi. ${ }^{1}$ Pendirian organisasi tersebut dengan tujuan pokok memelihara kepentingan dari sekelompok manusia tersebut. Demikian fungsi negara adalah menyelenggarakan kepentingan bersama dari anggota sekelompok yang disebut bangsa.

Fungsi politik merupakan fungsi dasar yang pertama kali muncul setelah negara lahir yang oleh karenanya, fungsi ini sering disebut sebagai fungsi negara yang klasik (the classical function of government). Fungsi ini meliputi dua aspek penting yakni pemeliharaan ketenangan dan ketertiban (maintenance of peace and order) serta pertahanan dan keamanan (security). Fungsi yuridis mewajibkan negara untuk mengatur tata bernegara dan bermasyarakat, agar supaya konflik-konflik yang tejadi dalam masyarakat dapat diselesaikan menurut criteria yang telah hidup dan diakui kebenarannya oleh masyarakat itu sendiri, yakni hukum. Fungsi administratif memberi kewajiban kepada negara untuk menata birokrasinya demi terwujudnya tujuan negara. ${ }^{2}$

Sejarah bangsa Indonesia tidak berjalan linier dalam pilihannya pengutamaan fungsi Negara antara fungsi regular dengan fungsi pembangunan. Indonesia harus mengutamakan fungsi pembangunan daripada fungsi regulernya. Sebaliknya, pada masa yang lain, Indonesia akan mengutamakan fungsi regulernya disbanding dengan fungsi pembangunan, namun sesuai dengan teori dengan kenegaraan, pelaksanaan kedua fungsi tersebut lebih tepat dilaksanakan secara selaras dan seimbang. ${ }^{3}$

Untuk mewujudkan kepastian hukum pada sebuah Negara yang berlandaskan hukum, haruslah didukung dengan keberadaan peraturan perundang-undangan yang cukup memadai dan mengakomodir semua

\footnotetext{
${ }^{1}$ Utrecht, E. (1985). Pengantar Hukum Administrasi Negara Indonesia. Cetakan Kedelapan, Jakarta: Balai Buku Ichtiar, p. 42.

${ }^{2}$ Muchsan. (1981). Beberapa Catatan tentang Hukum Administrasi Negara dan Peradilan Administrasi Negara di Indonesia. Yogyakarta: Liberty, p. 86.

${ }^{3}$ Handoyo, B. Restu Cipto. (2003). Hukum Tata Negara, Kewarganegaraan dan Hak Asasi Manusia (Memahami Proses Konsolidasi Sistem Demokrasi di Indonesia). Yogyakarta: Universitas Atma Jaya, p. 85.
} 
permasalahan dalam bidang hukum. Indonesia saat ini sudah memiliki Kitab Undang-Undang Hukum Pidana (KUHP), yang diwariskan secara turun temurun oleh pemerintah belanda. Saat ini KUHP merupakan substansi hukum yang kita miliki untuk mengatur serta mengakomodir semua permasalahan hukum terkait dengan hal pidana yang terjadi dalam wilayah Negara Kesatuan Republik Indonesia (NKRI).

Pada masa krisis moneter melanda indonesia yang dimulai sejak pertengahan tahun 1998 yang ditandai dengan nilai tukar rupiah yang menurun tajam serta resesi global, pemutusan hubungan kerja (PHK) massal menjadi sebuah keniscayaan. Di satu sisi, negara akan disibukkan menjalankan fungsinya yang reguler untuk mengembalikan kepercayaan masyarakat dan dunia internasional.

Di sisi lain masyarakatakan mencari pekerjaan alternatif untuk menompang kebutuhan hidupnya yang kian komplek. Pada saat inilah lapangan kerja informal menjadi pilihannya, salah satunya menjadi pedagang kaku lima (PKL). ${ }^{4}$ Munculnya PKL bagai cendawan di musim hujan di saat naiknya harga-harga kebutuhan pokok serta sulitnya memenuhi kebutuhan hidup. Kelompok ini (PKL) mencoba mengais rezeki dalam keterbatasan ilmu dan kemampuannya untuk mendapat pekerjaan yang lebih baik. Memanfaatkan celah ruang kosong di jalan ataupun trotoar yang merupakan fasilitas umum. Kebanyakan dari mereka melaksanakan aktifitasnya di ruang-ruang publik di kawasan perkotaan.

Terpakainya badan jalan atau trotoar sebagai lokasi berjualan tentunya akan mengganggu pengguna jalan yang lain. Sebagai sesama warga masyarakat yang tentunya memiliki hak yang sama dalam memanfaatkan fasilitas umum, hak pejalan kaki juga mestinya dilindungi oleh pemerintah. Namun di sisi lain, pemerintah juga tidak dibenarkan menggunakan kekuasaannya secara sewenang-wenang untuk mengosongkan fasilitas umum tersebut dari kegiatan yang dilakukan oleh PKL. Perlu pengaturan yang benar-benar bisa memihak dan menjamin terwujudnya kepentingan bersama.

Penertiban dan penggusuran yang dilakukan oleh Pemerintah Kota Bandar Lampung kerap diwarnai bentok fisik antara polisi pamong praja dengan pedagang kaki lima. Untuk melegalkan penertiban tersebut pemerintah Kota Bandar Lampung kemudian membuat sebuah peraturan daerah yang ditujukan kepada pedagang kaki lima. Peraturan tersebut yaitu Peraturan Daerah No. 8 Tahun 2000 tentang Pembinaan Umum Ketertiban, Keamanan, Kebersihan, Kesehatan, dan Keapikan dalam Wilayah Kota Bandar Lampung.

\footnotetext{
${ }^{4}$ Manan, Bagir. (1996). "Bentuk-Bentuk Perbuatan Keperdataan yang dappat dilakukan oleh Pemerintah Daerah", Majalah Ilmiah Universitas Padjajaran, 3(14).
} 
Membanjirnya PKL membutuhkan penanganan yang baik agar tidak menimbulkan kerugian pada kelompok masyarakat yang lain terutama pengguna jalan. Berikut ini Pasal yang mengatur tentang ketertiban umum yang menyangkut masalah keberadaan pedagang kaki lima. Perda No. 8 Tahun 2000 pada Bab III tentang Larangan Mempergunakan Fasilitas Umum, Pasal 16 ayat 1, 2, dan 3 tertulis jelas: ${ }^{5}$

1. Dilarang mempergunakan jalan umum atau trotoar atau pada teras depan bangunan pertokoan atau bangunan yang menghadap pada jalan umum oleh pedagang kaki lima atau usaha lainnya kecuali pada tempat-tempat yang ditentukan atau ditunjuk oleh walikota.

2. Dilarang mempergunakan pasar atau bangunan komplek pertokoan yang tidak bertingkat atau lantai I (satu) sebagai tempat bermukim.

3. Dilarang mempergunakan halaman pakir pada komplek pasar/pertokoan /plaza untuk tempat mirip atau menetap kendaraan atau gerobak dagangan.

Pembuat Perda membatasi definisi pedagang kaki lima (PKL) sebagai "pelaku usaha yang melakukan kegiatan usahanya dalam jangka waktu tertentu dan bersifat sementara di daerah milik jalan atau fasilitas umum, dengan menggunakan sarana berdagang yang mudah dipindahkan dan dibongkar pasang". Bagi pembuat Perda, salah satu upaya peningkatan kehidupan perekonomian rakyat adalah dengan memberika kesempatan bagi para pelaku usaha di sektor informal untuk menjalankan dan mengembangkan kegiatan usahanya secara maksimal dan berkesinambungan. Pedagang Kaki Lima sebagai salah satu unsur pelaku usaha di sektor informal, keberadaannya mempunyai pengaruh yang cukup besar bagi kehidupan roda perekonomian rakyat di Kota Bandar Lampung. Dalam perkembangannya, keberadaan pedagang kaki lima di kawasan perkotaan Kota Bandar Lampung telah menggunakan daerah milik jalan atau fasilitas umum menimbulkan gangguan ketentraman, ketertiban masyarakat, kebersihan lingkungan, dan kelancaran lalu lintas sehingga perlu dilakukan upaya pengaturan agar tercipta tertib sosial dan ketentraman masyarakat dengan mengikusertakan ketertiban masyarakat. ${ }^{6}$

Upaya pemerintah Kota Bandar Lampung dalam rangka mengatur keberadaan pedagang kaki lima adalah melalui kegiatan penataan lokasi usaha bagi pedagang kaki lima, pengaturan mekanisme pemberian perizinan, dan pengaturan mengenai pemberian sanksinya serta dengan melaksanakan upaya pemberdayaan terhadap pedagang kaki lima serta senantiasa

\footnotetext{
${ }^{5}$ Peraturan Daerah No. 8 Tahun 2000 tentang Pembinaan Umum, Ketertiban, Keamanan, Kebersihan, Kesehatan, dan Keapikan dalam Wilayah Kota Bandar Lampung.

${ }^{6}$ Pasaribu, Iqbal Tawakkal. (2006). Melihat Fenomena Pedagang Kaki Lima Melalui Aspek Hukum. Bandung: Universitas Islam Bandung, p. 33.
} 
melaksanakan pembinaan, pengawasan, dan pengendalian pedagang kaki lima secara terpadu dan berkesinambungan.

Dalam upaya pengaturan PKL, Peraturan Daerah mengatur pula adanya kewajiban mengajukan izin lokasi kepada Pemerintah Kota yang disertai pula dengan sanksi bagi pedagang kaki lima yang tidak memiliki izin. Salah satu sanksi yang diberlakukan adalah paksaan pemerintahan (dwangsom) berupa pembongkaran dan pengosongan lokasi yang digunakan oleh pedagang kaki lima yang tidak berizin. Pemerintah Kota merupakan Pejabat Tata Usaha Negara yang menjalankan fungsi administrasi. Sebagai pemerintah, pemerintah Kota Bandar Lampung merupakan subjek hukum sekaligus pendukung hak-hak dan kewajiban-kewajiban. Pemerintahpun juga diberi wewenang untuk melakukan berbagai tindakan, baik tindakan nyata (feitelijkhandelingen) maupun tindakan hukum (rechtshandelingen). ${ }^{7}$

Salah satu tindakan dalam penertiban PKL adalah sanksi kepada PKL yang tidak berizin berupa paksaan pemerintahan (dwangsom) ${ }^{8}$ Tulisan ini mengulas apa saja yang menjadi prasyarat bagi pelaksanaan paksaan pemerintahan (dwangsom), implementasi paksaan pemerintahan di Kota Bandar Lampung khususnya dalam penertiban PKL baru-baru ini serta mengapa terdapat penolakan yang begitu kuat dari kelompok PKL atas tindakan paksaan pemerintahan tersebut. Sekaligus tulisan ini hendak menguji implementasi paksaan pemerintahan oleh pemerintah Kota Bandar Lampung tersebut berdasarkan prespektif norma Hukum Administrasi.

Peran satuan polisi pamong praja tercakup dalam tugas dan fungsi satuan polisi pamong praja dalam rangka memelihara ketentraman dan menyelenggarakan ketertiban umum (trantibum) serta menegakkan produk hukum daerah (Perda) ${ }^{9}$ dan Peraturan Kepala Daerah merupakan salah satu komponen penegak hukum yang sangat penting. Berdasarkan Pasal 148 Undang-Undang Nomor 23 Tahun 2014 tentang Pemerintah Daerah serta Peraturan Pemerintah Nomor 32 Tahun 2004 tentang Pedoman Satuan Polisi Pamong Praja secara khusus disebutkan bahwa satuan polisi pamong praja mempunyai tugas memelihara dan menyelenggarakan ketenteraman dan ketertiban umum, penegakkan Peraturan Daerah dan Keputusan Kepala Daerah.

\footnotetext{
7 Pudyatmoko, Y. Sri dan Tjandra, W. Ridwan. (1996), Peradilan Tata Usaha Negara Sebagai Salah Satu Fungsi Kontrol Pemerintah. Yogyakarta: Universitas Atmajaya, p. 64.

${ }^{8}$ HR, Ridwan. (2006), Hukum Administrasi Negara. Jakarta: PT. Raja Grafindo Persada, p. 78.

${ }^{9}$ Peraturan Walikota Bandar Lampung Nomor 15 Tahun 2013 tentang Tugas, Fungsi, dan tata Kerja Satuan Polisi Pamong Praja Daerah Kota Bandar Lampung.
} 
Dalam melaksanakan tugas pokok memelihara dan menyelenggarakan ketenteraman dan ketertiban umum serta menegakkan produk hukum daerah, satuan polisi pamong praja menyelenggarakan fungsi yaitu: ${ }^{10}$

1. Penyusunan program dan pelaksanaan ketenteraman dan ketertiban umum, serta penegakan produk hukum daerah;

2. Pelaksanaan kebijakan pemeliharaan dan penyelenggaraan ketentraman dan ketertiban umum di daerah;

3. Pelaksanaan kebijakan penegakan produk hukum daerah;

4. Pelaksanaan kordinasi pemeliharaan dan penyelenggaraan ketenteraman dan ketertiban umum serta penegakan hukum daerah dengan aparat kepolisian negara, penyidik pegawai negeri sipil (PPNS) atau aparatur lainnya;

5. Pengawasan terhadap masyarakat agar mematuhi dan menaati produk hukum daerah;

6. Pelaksanaan tugas lain yang diberikan oleh walikota sesuai dengan tugas dan fungsinya.

Oleh karena itu anggota satuan polisi pamong praja berwenang melakukan tugas-tugas dibidang penegakkan hukum khususnya Peraturan Daerah.

Dengan adanya peraturan perundangan tersebut, maka untuk memelihara tugas-tugas di daerah, Peraturan Daerah Nomor 10 Tahun 1989 tentang Pengaturan dan Pembinaan Pedagang Kaki Lima dan Peraturan Daerah (Perda) Kota Bandar Lampung Nomor 08 Tahun 2000 tentang Pembinaan Umum, Ketertiban, Keamanan, Kebersihan, Kesehatan dan Keapikan dalam Wilayah Kota Bandar Lampung serta Peraturan Walikota Bandar Lampung Nomor 15 Tahun 2013 tentang Tugas, Fungsi, dan Tata Kerja Satuan Polisi Pamong Praja Kota Banda Lampung yang sangat strategis dalam upaya menumbuhkembangkan kepatuhan masyarakat terhadap Peraturan Daerah dan Keputusan Kepala Daerah yang sangat berdampak kepada Pendapatan Asli Daerah (PAD) sebagai penunjang suksesnya pelaksanaan otonomi daerah. Upaya untuk membangun, menjaga ketenteraman dan ketertiban umum serta stabilitas keamanan memerlukan dukungan, kerjasama serta komitmen bersama. Menyadari kesulitan yang mungkin timbul terutama dalam penyatuan persepsi, mengatasi kendala situasi dan kondisi di lapangan, kecepatan dalam penanganannya, maka diperlukan koordinasi antar instansi terkait.

Dalam melaksanakan tugas-tugas tersebut diatas satuan polisi pamong praja Kota Bandar Lampung didukung sumber daya manusia yang relatif terbatas dibanding tugas yang diemban, dengan jumlah personil yang terdiri

10 Pasal 4 Peraturan Walikota Bandar Lampung Nomor 15 Tahun 2013 tentang Tugas, Fungsi, dan Tata Kerja Satuan Polisi Pamong Praja Daerah Kota Bandar Lampung. 
dari berstatus pegawai negeri sipil, PPNS yang berjumlah dua orang, tenaga honorer dan tenaga harian lepas. Adapun klasifikasi pindidikan formal yang ada adalah berpendidikan pascasarjana, sarjana, sarjana muda, SLTA, SLTP dan SD.

Pendekatan masalah dalam penulisan ini menggunakan metode pendekatan yuridis normative dan yuridis empiris. Adapun jenis dan sumber data yang digunakan dalam penulisan ini terdiri dari data primer yang bersumber dari lapangan dan data sekunder bersumber dari perpustakaan. Data yang telah diperoleh kemudian dianalisis secara kualitatif yang pokok bahasan akhirnya menuju pada suatu kesimpulan ditarik dengan metode induktif.

\section{B. Pembahasan}

\section{Kebijakan Hukum Pidana terhadap Pembatasan Kewenangan dalam Penyidikan Notaris}

Di kota-kota besar keberadaan Pedagang Kaki Lima (yang selanjutnya disebut PKL) merupakan suatu fenomena kegiatan perekonomian rakyat kecil. Akhir-akhir ini fenomena penggusuran terhadap para PKL marak terjadi. Para PKL digusur oleh aparat pemerintah seolah-olah mereka tidak memiliki hak asasi manusia dalam bidang ekonomi sosial dan budaya (EKOSOB). ${ }^{11}$ Melihat PKL ini merupakan fenomena kegiatan perekonomian rakyat kecil, yang mana mereka berdagang hanya untuk memenuhi kebutuhan pokoknya sehari-hari.

Pedagang Kaki Lima ini timbul dari adanya suatu kondisi pembangunan perekonomian dan pendidikan yang tidak merata diseluruh NKRI (Negara Kesatuan Republik Indonesia) ini. PKL ini juga timbul dari akibat tidak tersedianya lapangan pekerjaan bagi rakyat kecil yang tidak memiliki kemampuan dalam berproduksi. Pemerintah dalam hal ini sebenarnya memiliki tanggung jawab didalam melaksanakan pembangunan bidang pendidikan, bidang perekonomian dan penyediaan lapangan pekerjaan. Ketentuan ini diatur dalam peraturan perundang-undangan yang tertinggi yaitu UUD 1945.

Dengan adanya pengaturan mengenai tanggung jawab pemerintah dalam UUD 1945, hal ini menunjukkan bahwa negara kita adalah negara hukum. Segala hal yang berkaitan dengan kewenangan, tanggung jawab, kewajiban, dan hak serta sanksi semuanya diatur oleh hukum. Peningkatan kemampuan daerah untuk secara kreatif dan optimal mendayagunakan kewenangan-kewenangan yang telah dilimpahkan oleh pemerintah seperti

\footnotetext{
${ }^{11}$ Pasaribu, Iqbal Tawakkal. Op. Cit., p. 12.
} 
yang terinci dalam PP No. 25 Tahun 2000. ${ }^{12}$ Ketentuan-ketentuan yang mengatur mengenai tanggung jawab pemerintah dalam bidang pendidikan, perekonomian dan penyediaan lapangan pekerjaan belum pernah terealisasi secara sempurna. Hal ini dapat dibuktikan dengan besarnya jumlah rakyat miskin di indonesia. Kemiskinan ini diakibatkan oleh tidak adanya pemerataan kemajuan perekonomian, peningkatan kwalitas pendidikan dan penyediaan lapangan pekerjaan oleh pemerintah.

Maraknya PKL berbuntut pada munculnya berbagai persoalan. Ada anggapan bahwa keberdaaan PKL yang semrawut dan tidak teratur mengganggu ketertiban, keindahan serta kebersihan lingkungan. Lokasi berdagang yang sembarangan bahkan cenderung memakan bibir jalan sangat mengganggu lalu lintas baik bagi pejalan kaki maupun pengendara motor dan mobil. Selain itu, parker kendaraan para pembeli yang tidak teratur juga sangat mengganggu ketertiban. Selama ini para PKL belum sadar akan pentingnya kebersihan sehingga keindahan di lingkungan pun sulit diwujudkan.

Selain ruas jalan, beberapa lampu lalu lintas (traffic light) yang sudah tidak lagi (kurang berfungsi) turut menjadi penyebab meningkatnya angka kemacetan di Bandar Lampung. Faktor lainnya yang menyumbang angka kemacetan terbesar yaitu pedagang kaki lima (PKL). Tak bias dielakkan aktivitas PKL, khusunya yang ada di sekitar jalan Protokol (jalan-jalan di pusat kota) yang menggunakan badan jalan ikut menyumbang kemacetan. Kemacetan terjadi juga terutama didaerah pasar-pasar itu dipenuhi pedagang kaki lima (PKL).

Fenomena pedagang kaki lima (PKL) ini merupakan imbas dari semakin banyaknya jumlah rakyat miskin di indonesia. Mereka berdagang hanya karena tidak ada pilihan lain, mereka tidak memiliki kemampuan pendidikan yang memadai, dan tidak memiliki tingkat pendapatan ekonomi yang baik dan tidak adanya lapangan pekerjaan yang tersedia buat mereka. Sehingga untuk memenuhi kebutuhan pokok sehari-hari dan untuk membiayai keluarganya ia harus bedagang di kaki lima. ${ }^{13}$ Mengapa pilihannya adalah pedagang kaki lima, karena pekerjaan ini sesuai dengan kemampuan mereka, yaitu modalnya tidak besar, tidak membutuhkan pendidikan yang tinggi dan mudah untuk di kerjakan. Mereka punya naluri dimana kira-kira tempat strategis yang ramai didatangi pembeli. ${ }^{14}$

12 Rasyid, Ryaas. (2007). Desentralisai dan Otonomi Daerah, Otonomi Daerah, Latar Belakang dan Masa Depannya. Jakarta: Penerbit LIPI Press, p. 12.

13 Rahardjo, Satjipto (2009). Masalah Penehgakkan Hukum Dalam Suatu Tinjauan Sosiologis. Bandung: Sinar Baru, p. 8.

14 Pandue, Marthias Dusky. (2010). Jernih Melihat Cermat Mencatat, Antologi Karya Jurnalistik Wartawan Senior Kompas. Jakarta: PT Kompas Media Sarana, p. 300-302. 
Di NKRI ini belum ada Undang-undang yang khusus mengatur pedagang kaki lima (PKL). Padahal fenomena pedagang kaki lima (PKL) sudah merupakan permasalahan yang pelik dan juga sudah merupakan permasalahan nasional, karena disetiap kota pasti ada pedagang kaki limanya. Pengaturan mengenai pedagang kaki lima hanya terdapat dalam peraturan daerah (Perda). Perda ini hanya mengatur tentang pelarangan untuk berdagang bagi PKL di daerah-daerah yang sudah ditentukan. Namun mengenai hak-hak PKL ini tidak diatur didalam perda tersebut. Untuk Kota Bandar Lampung, ketentuan mengenai PKL ini diatur didalam Peraturan Daerah Nomor 8 Tahun 2000.

\section{Perlindungan Hukum Bagi Pedagang kaki Lima (PKL)}

Walaupun tidak ada pengaturan khusus tentang hak-hak pedagang kaki lima, namun kita dapat menggunakan beberapa produk hukum yang dapat dijadikan landasan perlindungan bagi pedagang kaki lima. Ketentuan perlindungan hukum bagi para pedagang kaki lima ini adalah :

a. Pasal 27 ayat (2) UUD 1945 "Tiap-tiap warga negara berhak atas pekerjaan dan penghidupan yang layak bagi kemanusiaan".

b. Pasal 11 UU Nomor 39 / 1999 mengenai Hak Asasi Manusia : "Setiap orang berhak atas pemenuhan kebutuhan dasarnya untuk tumbuh dan berkembang secara layak".

c. Pasal 38 UU Nomor 39 / 1999 mengenai Hak Asasi Manusia :

1) "Setiap warga negara, sesuai dengan bakat, kecakapan dan kemampuan, berhak atas pekerjaan yang layak.

2) Setiap orang berhak dengan bebas memilih pekerjaan yang di sukainya dan ......"

d. Pasal 13 UU Nomor 09 / 1995 tentang usaha kecil: "Pemerintah menumbuhkan iklim usaha dalam aspek perlindungan, dengan menetapkan peraturan perundang-undangan dan kebijaksanaan untuk:

1) Menentukan peruntukan tempat usaha yang meliputi pemberian lokasi di pasar, ruang pertokoan, lokasi sentra industri, lokasi pertanian rakyat, lokasi pertambangan rakyat, dan lokasi yang wajar bagi pedagang kaki lima, serta lokasi lainnya.

2) Memberikan bantuan konsultasi hukum dan pembelaan.

Dengan adanya beberapa ketentuan diatas, pemerintah dalam menyikapi fenomena adanya pedagang kaki lima, harus lebih mengutamakan penegakan keadilan bagi rakyat kecil. Walaupun didalam Peraturan Daerah K3 (kebersihan, keindahan, dan ketertiban) terdapat pelarangan pedagang kaki lima untuk berjualan di trotoar, jalur hijau, jalan, dan badan jalan, serta tempat-tempat yang bukan peruntukkannya, namun pemerintah harus 
mampu menjamin perlindungan dan memenuhi hak-hak ekonomi pedagang kaki lima (PKL). ${ }^{15}$

\section{Hak-Hak Pedagang Kaki Lima Terhadap Pembongkaran}

Fenomena dalam pembongkaran para PKL ini sangat tidak manusiawi. Pemerintah selalu menggunakan kata penertiban dalam melakukan pembongkaran. Sangat disayangkan ternyata didalam melakukan penertiban sering kali terjadi hal-hal yang ternyata tidak mencerminkan katakata tertib itu sendiri. Kalau kita menafsirkan kata penertiban itu adalah suatu proses membuat sesuatu menjadi rapih dan tertib, tanpa menimbulkan kekacauan atau masalah baru. ${ }^{16}$

Pemerintah dalam melakukan penertiban sering kali tidak memperhatikan, serta selalu saja merusak hak milik para pedagang kaki lima atas barang-barang dagangannya. Padahal hak milik ini telah dijamin oleh UUD 1945 dan Undang-Undang Nomor 39 Tahun 1999 mengenai Hak Asasi Manusia. Diantaranya berbunyi sebagai berikut:

a) Pasal 28 G ayat (1) UUD 1945, berbunyi "setiap orang berhak atas perlindungan diri pribadi, keluarga, kehormatan, martabat, dan harta benda yang dibawah kekuasaannya, serta berhak atas rasa aman dan perlindungan dari ancaman ketakutan untuk berbuat atau tidak berbuat sesuatu yang merupakan hak asasi”.

b) Pasal $28 \mathrm{H}$ ayat (4) UUD 1945, berbunyi "setiap orang berhak mempunyai hak milik pribadi dan hak milik tersebut tidak boleh diambil alih secara sewenang-wenang".

c) Pasal 28 I ayat (4) UUD 1945, berbunyi "Perlindungan, pemajuan, penegakan, dan pemenuhan hak asasi manusia adalah tanggung jawab negara terutama pemerintah".

Sedangkan didalam Undang-Undang Nomor 39 Tahun 1999 mengenai HAM, berbunyi sebagai berikut :

a) Pasal $36 \mathrm{G}$ ayat (2) berbunyi "tidak seorang pun boleh dirampas hak miliknya dengan sewenang-wenang".

b) Pasal 37 ayat (1) berbunyi "pencabutan hak milik atas sesuatu benda demi kepentingan umum, hanya dapat diperbolehkan dengan mengganti kerugian yang wajar dan segera diperbolehkan dengan mengganti kerugian yang wajar dan serta pelaksanaannya sesuai dengan peraturan perundang-undangan yang ada.

${ }^{15}$ Rujukan pada Peraturan Daerah (Perda) Kota Bandar Lampung Nomor 08 Tahun 2000 Tentang Pembinaan Umum, Ketertiban, Keamanan, Kebersihan, Kesehatan Dan Keapikan Dalam Wilayah Kota Bandar Lampung.

16 Marbun, S.F. (1997). Peradilan Administrasi Negara dan Upaya Administratif di Indonesia, Edisi Pertama. Yogyakarta: Liberty, p. 335. 
c) Pasal 37 ayat (2) berbunyi "apabila ada sesuatu benda berdasarkan ketentuan hukum demi kepentingan umum harus dimusnahkan atau tidak diberdayakan baik itu untuk selama-lamanya maupun untuk sementara waktu, maka hal itu dilakukan dengan mengganti kerugian.

d) Pasal 40 berbunyi "setiap orang berhak untuk bertempat tinggal serta berkehidupan yang layak".

Pemerintah didalam melakukan penertiban harusnya memperhatikan dan menjunjung tinggi hak milik para PKL atas barang dagangannya. Ketika pemerintah melakukan pengrusakan terhadap hak milik para PKL ini, maka ia sudah melakukan perbuatan melanggar hukum, yakni ketentuan yang terdapat dalam hukum pidana dan juga ketentuan yang terdapat didalam hukum perdata. Adapun ketentuan yang diatur didalam hukum pidana adalah Pasal 406 ayat (1) KUHP berbunyi : "Barang siapa dengan sengaja dan dengan melawan hak membinasakan, merusakkan, membuat sehingga tidak dapat dipakai lagi atau menghilangkan sesuatu barang yang sama sekali atau sebagiannya kepunyaan orang lain, dihukum penjara selama-lamanya dua tahun delapan bulan. Sedangkan ketentuan yang diatur didalam hukum perdatanya adalah Pasal 1365 berbunyi: "tiap perbuatan melanggar hukum, yang membawa kerugian pada orang lain, mewajibkan orang yang karena salahnya menerbitkan kerugian itu, mengganti kerugian tersebut".

Menegakkan sesuatu hukum dan keadilan, ketika cara (metode) yang dipergunakan justru melawan hukum. Adapun alasannya PKL ini tidak dapat disalahkan secara mutlak. Harus diakui juga memang benar bahwa PKL melakukan suatu perbuatan pelanggaran terhadap ketentuan yang ada didalam perda. Akan tetapi pemerintah juga telah melakukan suatu perbuatan kejahatan ketika ia melakukan pengrusakan atas hak milik barang dagangan PKL, dan pemerintah juga harus mengganti kerugian atas barang dagangan PKL yang dirusak. Sebaliknya kelompok yang kontra berpendapat sektor informal ini sebagai biang kemacetan lalu lintas, sumber kesemrawutan kota, kumuh, beperan dalam meningkatkan pencemaran lingkungan kota, dan seterusnya. ${ }^{17}$

Pemerintah belum pernah memberikan suatu jaminan yang pasti bahwa ketika para PKL ini di gusur, mereka harus berjualan di tempat seperti apa. Jangan-jangan tempat yang dijadikan relokasi para PKL tersebut, ternyata bukanlah suatu pusat perekonomian. Sekarang ini penguasaan pusat kegiatan perekonomian justru di berikan pada pasar-pasar hipermart atau pasar modern dengan gedung yang tinggi serta ruangan yang ber AC. Para pedagang kecil hanya mendapatkan tempat pada pinggiran-pinggiran dari kegiatan perekonomian tersebut.

${ }^{17}$ Iwanto, Sutrisno. (2001). Kiat Sukses berwiraswasta, Strategi Baaru Mengelola Usaha Kecil dan Menengah. Jakarta: PT Grasindo Grameia Widia sarana, p. 10-11. 


\section{Faktor-Faktor Penghambat Dalam Tegaknya Pengaturan terhadap Perda}

Dari segi hukum dan kepentingan penertiban tata kota, kehadiran pedagang kaki lima (yang selanjutnya disebut PKL) yang sering kali sampai memakan separuh badan jalan dan menduduki tanah-tanah kosong tanpa izin resmi jelas melanggar hukum dan menggangu ketertiban. Suasana kumuh, semrawut, bergelantungan spanduk yang tak beraturan, tikar-tikar yang berserakan, semuanya mungkin terasa tak sedap dipandang mata. Tetapi, sekadar menggusur PKL dan menyita barang dagangan mereka tanpa ditindaklanjuti dengan berbagai bentuk pembinaan dan penanganan yang komprehensif, niscaya tak akan pernah menyelesaikan masalah. Untuk menata PKL dengan baik dibutuhkan sebuah konsep penanganan yang benar-benar komprehensif dan menyentuh akar persoalan yang sebenarnya.

Mengingat segala keterbatasan jumlah personil untuk terus-menerus melakukan penertiban, keterbatasan dana dan lahan yang dimiliki pemerintah kabupaten/kota untuk menampung PKL, maka upaya untuk menata PKL harus melibatkan pihak swasta atau kalangan dunia usaha, khususnya pusat-pusat kegiatan ekonomi yang berskala besar seperti pasar modern, pusat perkantoran, plaza, atau mal.Khususnya untuk PKL yang menjual makanan, misalnya, jelas merupakan kebutuhan yang tak terelakkan untuk melayani pegawai atau orang-orang yang bekerja di plaza, pusat perkantoran, atau pusat keramaian yang lain.

Salah satu contoh hubungan simbiosis-mutualisme antara pengelola pusat keramaian dan PKL biasa dilihat di pasar. Untuk mengurangi perkembangan jumlah PKL yang berlebihan di berbagai wilayah, ada baiknya jika berbagai dinas dan jajaran aparat di lingkungan pemerintah kabupaten/kota tidak melulu terjebak pada pendekatan yang sifatnya represif dan kuratif. Melainkan juga mencoba mengembangkan semacam mekanisme deteksi dini yang efektif melalui keterlibatan dan peran aparat di tinggat kelurahan dan kecamatan.

Di Bandar Lampung, kesemrawutan yang terjadi di wilayah kota dan sekitar pasar salah satu contoh yangbisa disebut dengan dalih Peraturan Daerah (Perda) Nomor 10 Tahun 1989 tentang Pengaturan dan Pembinaan Pedagang Kaki Lima dan didukung oleh Peraturan Daerah (Perda) Kota Bandar Lampung Nomor 08 Tahun 2000 tentang Pembinaan Umum, Ketertiban, Keamanan, Kebersihan, Kesehatan dan Keapikan dalam Wilayah Kota Bandar Lampung serta Peraturan Walikota Bandar Lampung mengeluarkan Nomor 15 Tahun 2013 tentang Tugas, Fungsi dan Tata Kerja Satuan Polisi Pamong Praja Kota Bandar Lampung yang sangat strategis dalam upaya menumbuhkembangkan kepatuhan masyarakat terhadap Peraturan Daerah. 
Tantangan ke depan adalah bagaimana mengombinasikan antara kegiatan pembinaan, pengawasan, dan upaya preventif, serta kegiatan penindakan itu sendiri untuk situasi khusus. ${ }^{18}$ Untuk kegiatan pembinaan dan pemberdayaan PKL, penting dilakukan terutama bagi para PKL yang termasuk kelompok binaan dan para PKL yang tidak lagi diperbolehkan berdagang di kawasan yang dilarang. Sedangkan kegitan pengawasan rutin dibutuhkan untuk mencegah agar daerah atau kawasan yang sudah ditertibkan dan bersih dari PKL tidak lagi dihuni PKL lama atau PKL baru yang menurut ketentuan memang dilarang berdagang di kawasan itu. ${ }^{19}$

Untuk kegiatan yang sifatnya preventif atau pencegahan, maka pihak yang semestinya bertanggung jawab adalah aparat di tingkat kecamatan dan kelurahan. Efektivitas dan sikap pro-aktif pihak kecamatan dan kelurahan dapat dijamin kelangsungannya jika didukung oleh anggaran rutin operasional yang memadai dan dukungan personil yang cukup. Melakukan patroli mobil secara rutin, misalnya, tidak mungkin dapat dilakukan pihak kecamatan jika mereka tidak memiliki sarana dan dukungan dana untuk melakukan hal itu.

Sebagai sebuah masalah sosial, persoalan PKL sebetulnya adalah masalah yang kompleks dan sulit terpecahkan secara instan karena kemunculan mereka pada hakikatnya adalah produk dan implikasi dari berbagai kekeliruan kebijakan pembangunan wilayah yang sudah puluhan tahun berjalan dari elite politik satu ke elite politik berikutnya. Pengalaman telah menunjukkan, berbagai masalah sosial yang muncul di kota besar dan kota menengah pada dasarnya adalah imbas dari terjadinya kesengajaan antar wilayah dan arus urbanisasi yang berlebihan (over urbanization).

Keberadaan sektor informal, terutama PKL, sesungguhnya adalah jawaban spontan dan penuh prakarsa dari masyarakat yang termarjinalisasi terhadap tekanan situasi dan faktor-faktor struktural yang mengimpit mereka. Jika pemerintah kabupaten/kota yang ada di lampung hanya melakukan tindakan penggusuran dan merampas lapak-lapak tempat mereka menggantungkan hidup, maka bagi para PKL itu sesungguhnya sama dengan membunuh masa depan mereka dan sanak keluarganya. Tidaklah kita tergugah untuk mencari solusi yang lebih arif dan empatif bagi para PKL.

${ }^{18}$ Surat harian Kompas. Penertiban PKL di Surabaya Parsial dan Diskriminatif. Senin, 29 Juli 2013.

${ }^{19}$ Pudyatmoko, Y. Sri dan Tjandra, W. Ridwan. (1996). Peradilan Tata Usaha Negara Sebagai Salah Satu Fungsi Kontrol Pemerintah. Yogyakarta: Universitas Atmajaya, p. 67. 


\section{Tugas, Fungsi dan Tata Kerja Satuan Polisi Pamong Praja Daerah Kota Bandar Lampung}

Dalam Peraturan Walikota Bandar Lampung Nomor 15 Tahun 2013 tentang Tugas, Fungsi dan Tata Kerja Satuan Polisi Pamong Praja Daerah Kota Bandar Lampung di jelaskan, bahwa Satuan Polisi Pamong Praja merupakan unsur penunjang Pemerintah Daerah dalam rangka mendukung pelaksanaan tugas-tugas pemerintah Kota Bandar Lampung dibidang ketentraman dan ketertiban masyarakat. Pada Peraturan Walikota Kota Bandar Lampung Nomor 15 Tahun 2013 Pasal 2 diatur, Bahwa kedudukan seorang Kepala Satuan Polisi Pamong Praja langsung bertanggung jawab kepada Walikota melalui Sekretaris Daerah.

Polisi Pamong Praja mempunyai tugas pokok membantu Walikota dalam menyelenggarakan tugas pemerintah di bidang ketentraman dan ketertiban masyarakat dan Penegakan Peraturan produk hukum daerah. Berdasarkan Pasal 4 Peraturan Walikota Bandar Lampung Nomor 15 Tahun 2013 tentang tugas, fungsi, dan tata kerja satuan polisi pamong praja daerah Kota Bandar Lampung bahwa untuk menyelenggarakan tugas pokok tersebut, Fungsi Polisi Pamong Praja:

a. Penyusunan program dan pelaksanaan ketentraman dan ketertiban umum, serta penegakan produk hukum daerah;

b. Pelaksanaan kebijakan pemeliharaan dan penyelenggaraan ketentraman dan ketertiban umum di daerah

c. Pelaksanaan kebijakan penegakan produk hukum daerah.

d. Pelaksanaan koordinasi pemeliharaan dan penyelenggaraan ketentraman dan ketertiban umum serta penegakan hukum daerah dengan aparat kepolisian negara, Penyidik Pegawai Negeri Sipil (PPNS) atau aparatur lainnya.

e. Pengawasan terhadap masyarakat agar mematuhi dan menaati produk hukum daerah.

f. Pelaksanaan tugas lain yang diberikan oleh Walikota sesuai dengan tugas dan fungsinya.

Dengan adanya kewenangan yang diberikan kepada satuan polisi pamong praja, tidak dapat dipungkiri bahwa keberadaan satuan polisi pamong praja sangat penting dan stratrgis dalam penyelenggaraan pemerintahan daerah sesuai dengan lingkup tugasnya, termasuk di dalamnya penyelenggraan perlindungan masyarakat. Sebagai sebuah masalah sosial di kota besar, harus diakui bahwa upaya menata pedagang kaki lima dan menertibkan bangunan liar di Kota Bandar Lampung bukanlah hal yang mudah. Hal tersebut yang dapat merugikan satuan polisi pamong praja dimana dengan adanya ppedagang kaki lima yang kembali berjualan ditempat semula dapat merugikan nilai positif dari kinerja dan satuan polisi 
pamong praja dianggap tidak professional dalam menjalankan tugas dan fungsinya dalam menjaga ketertiban umum.

\section{Hambatan-Hambatan dalam Tugas Satuan Polisi Pamong Praja terhadap Pengaturan dan Pembinaan Pedagang Kaki Lima di Kota Bandar Lampung}

Hasil wawancara dengan Herman Karim Kabid ketertiban umum dan ketentraman masyarakat pada kantor polisi pamong praja Kota Bandar Lampung bahwa di dalam melaksanakan kegiatan walaupun telah direncanakan dengan terarah, pasti akan terdapat hambatan atau kendala. Begitu juga dengan polisi pamong praja dalam menegakkan Penegakan Hukum Peraturan Daerah Nomor 8 Tahun 2000 tentang Pembinaan umum, ketertiban, keamanan, kebersihan, kesehatan, dan keapikan dalam Wilayah Kota Bandar Lampung yang datangnya bisa didalam (intern) maupun dari luar (external).

Polisi Pamong Praja dalam melaksanakan tugas penegakan Peraturan Daerah mempunyai hambatan. Hambatan-hambatan tersebut adalah:

a. Kelembagaan: Meskipun sudah ada program kerja tahunan tentang rencana operasional pembinaan dan penegakan Peraturan Daerah terhadap pedagang kaki lima dan Keputusan Kepala Daerah, namun pada pelaksanaan masyarakat di daerah cenderung tidak taat pada peraturan yang berlaku.

b. Sumber Daya Manusia: Adanya tuntutan masyarakat terhadap kecepatan pelayanan oleh aparat, namun kemampuan dan keterampilan teknis operasi terhadap pedagang kaki lima kurang memadai.

c. Jaringan Kerja: Kurangnya kerjasama dengan instansi terkait dalam rangka penegakan Peraturan Daerah terhadap pedagang kaki lima dan kurangnya peraturan yang mendasari tentang koordinasi Polisi Pamong Praja dengan instansi lainnya.

d. Lingkungan yang belum kondusif: Saranan dan prasarana pendukung teknis operasional pembinaan ketenteraman dan ketertiban serta penegakan Peraturan Daerah terhadap pedagang kaki lima masih kurang. Di sisi lain terjadi penurunan tingkat kesadaran dan ketaatan masyarakat terhadap peraturan yang berlaku mengenai pedagang kaki lima.

Adapun materi yang dimuat dalam peraturan pemerintah ini meliputi susunan organisa, formasi, kedudukan, wewenang, hak, tugas dan kewajiban satuan polisi pamong praja. Khusus, mengenai fungsi dan peran dari satuan polisi pamong praja diatur dalam beberapa Pasal, yaitu: Pasal 3 yang menyebutkan "Satuan Polisi Pamong Praja mempunyai tugas memelihara dan menyelenggarakan ketenteraman dan ketertiban umum, menegakkan 
Peraturan Daerah dan Keputusan Kepala Daerah", Pasal 4 menyebutkan: "Dalam melaksanakan tugas sebagaimana dimaksud dalam Pasal 3, Satpol PP menyelenggarak fungsi:

a. Penyusunan program dan pelaksanaan ketenteraman dan ketertiban umum, penegakan Peraturan Daerah dan Keputusan Kepala Daerah;

b. Pelaksanaan kebijakan pemeliharaan dan penyelenggaraan ketenteraman dan ketertiban umum di Daerah;

c. Pelaksanaan koordinasi pemeliharaan dan penyelenggaraan ketenteraman dan ketertiban umum serta penegakan Peraturan Daerah, Keputusan Kepala Daerah dengan aparat Kepolisian Negara, PPNS dan aparatur lainnya;

d. Pengawasan terhadap masyarakat agar mematuhi dan menaati Peraturan Daerah dan Keputusan Kepala Daerah.

Pola-pola preventif pun dapat diupayakan guna menanggulangi suatu keadaan yang pontensial memunculkan berbagai gangguan kamtibmas. Khusus berkaitan dengan eksistensi satuan polisi pamong praja dalam penegakan hukum (represif), sebagai perangkat pemerintah daerah, kontribusi satuan polisi pamong praja sangat diperlukan guna mendukung suksesnya pelaksanaan Otonomi Daerah. Dengan demikian aparat polisi pamong praja diharapkan menjadi motivator dalam menjamin kepastian pelaksanaan peraturan daerah dan upaya menegakannya ditengah-tengah masyarakat, sekaligus membantu dalam menindak segala bentuk penyelewengan dan penegakkan hukum.

Sedangkan dalam pelaksanaan penjagaan ketertiban, kekurangan yang ada berupa minimnya anggota polisi pamong praja dalam berjaga dan berpatroli serta tidak bertanggung jawabnya anggota polisi pamong praja dalam melakukan penjagaan. Kondisi tersebut yang dimanfaatkan oleh pedagang untuk kembali berjualan ditempat yang dilarang, sehingga keadaan yang tertib masih jauh dari yang diharapkan. Didasarkan kondisi dan situasi yang berhasil diamati dari observasi yang dilakukan peneliti, maka untuk menganalisis proses pelaksanaan penertiban dan penjagaan ketertiban demi memperoleh seberapa besar kualitas keprofesionalan Satuan polisi pamong praja dalam melaksanakan kegiatan tersebut. Memang diakui sampai sekarang manusia meskipun kecewa terhadap hukum bahkan kadang-kadang hukum membawa konfrontasi manusia dengan manusia, manusia tetap memerlukan hukum, karena hal itu merupakan nilai dan kebutuhan asasi bagi manusia beradab. ${ }^{20}$

Dalam melaksanakan kewenangannya guna menegakkan peraturan daerah serta keputusan kepala daerah, sebagai salah satu tugas utama dari

${ }^{20}$ Prasetyo, Teguh. Disampaikan dalam Orasi Dies Natalis UNISRI ke XXVI Surakarta, Webs Universitas Slamet Riyadi, Tanggal 21 Juni 2006. 
polisi pamong praja, tentunya tidak semudah membalikkan telapak tangan, terlebih dalam melaksanakan kewenangannya ini polisi pamong praja dibatasi oleh kewenangan represif yang sifatnya non yustisial. Karenanya, aparat polisi pamong praja seringkali harus menghadapi berbagai kendala ketika harus berhadapan dengan masyarakat yang memiliki kepentingan tertentu dalam memperjuangkan kehidupannya, yang akhirnya bermuara pada munculnya konflik (bentrokan).

Hasil wawancara dengan Herman Karim, Kabid ketertiban umum dan ketenteraman masyarakat, satuan polisi pamong praja Kota Bandar Lampung bahwa fungsi polisi pamong paraja dalam menegakkan Peraturan Daerah di Kota Bandar Lampung cukup berperan karena polisi pamong praja sudah melaksanakan tugas pokok yaitu membantu Walikota atau Kepala Daerah dalam melaksanakan tugas pemerintahan dibidang ketenteraman dan ketertiban masyarakat serta penegakan Peraturan Daerah. Polisi pamong praja sudah cukup berperan dalam rangka penegakan peraturan daerah dengan melakukan kegiatan penyuluhan, mengadakan operasi dengan sistem stasioner, operasi dengan system hunting (mobill), mengadakan patrolipatroli rutin dan kewilayahan, mengadakan penjagaan tempat-tempat rawan, pembinaan sarana lalu lintas.

Pemerintah atau administrasi Negara merupakan subjek hukum, sebagai drager van de rechten en plichten atau sebagai pendukung hak-hak dan kewajiban-kewajiban. Sebagaimana subjek hukum lainnya perorangan maupun badan hukum, pemerintahpun melakukan berbagai tindakan, baik tindakan nyata (feitelijkhandelingen) maupun tindakan hukum (rechtshandelingen). Pengertian tindakan nyata adalah tindakan-tindakan yang tidak ada kaitannya dengan hukum sehingga tidak menimbulkan akibat hukum, sedangkan tindakan hukum adalah tindakan yang berdasar sifatnya dapat menimbulkan akibat hukum tertentu atau tindakan tersebut dimaksudkan untuk menciptakan hak dan kewajiban. ${ }^{21}$

Pengertian tindakan hukum pemerintah adalah tindakan-tindakan yang dilakukan oleh organ pemerintahan atau administrasi negara yang dimasudkan untuk menimbulkan akibat hukum tertentu dalam bidang pemerintahan atau administrasi negara. Berdasarkan pengertian itu Muchsan ${ }^{22}$ menyebutkan unsur-unsur tindakan hukum pemerintahan yaitu:

a. Perbuatan itu dilakukan oleh aparat pemerintah dalam kedudukannya sebagai penguasa maupun sebagai alat perlengkapan pemerintahan (bestuursorganen) dengan prakarsa dan tanggung jawab sendiri.

${ }^{21}$ HR, Ridwan. (2006). Hukum Administrasi Negara. Jakarta: PT Raja Grafindo Persada, p. 26.

${ }^{22}$ Ibid., p. 98. 
b. Perbuatan tersebut dilaksanakan dalam rangka menjalankan fungsi pemerintahan.

c. Perbuatan tersebut dimaksudkan sebagai sarana untuk menimbulkan akibat hukum di bidang hukum administrasi.

d. Perbuatan yang bersangkutan dilakukan dalam rangka pemeliharaan kepentingan negara dan masyarakat.

Upaya penertiban padagang kaki lima di Bandar Lampung berawal dari Peraturan Daerah Kota Nomor 10 Tahun 1989 tentang Pengaturan dan Pembinaan Pedagang Kaki Lima, dengan adanya Peraturan Daerah tersebut Pemerintah Kota Bandar Lampung memberi perhatian kembali pada tahun 2000 dengan mengundangkan Peraturan Daerah Nomor 08 Tahun 2000 tentang Pembinaan, Ketertiban, Keamanan, Kebersihan, Kesehatan dan Keapikan Dalam Wilayah Kota Bandar Lampung tersebut. Sebagai tindakan Pemerintah Kota Bandar Lampung terhadap pedagang kaki lima maka membentuk tim penataan pedagang kaki lima dalam wilayah daerahBandar Lampung sesuai Keputusan Walikota BandarLampung Nomor 45 / 10 / HK / 2008. Pembentukan Tim tersebut dimaksud untuk tugas sebagai berikut:

a. Melakukan sosialisasi / penyuluhan terhadap pedagang kaki lima dalam wilayah Kota Bandar Lampung.

b. Melakukan Penataan dan penempatan pedagang kaki lima pada tempattempat yang diperkenankan untuk berdagang.

c. Melakukan Pemantauan terhadap proses jalannya relokasi pedagang kaki lima ke tempat-tempat yang telah disediakan dan ditentukan.

d. Melakukan Pembongkaran dan penyimpanan tempat/alat berdagang pedagang kaki lima di tempat terlarang.

e. Melaporkan hasil penataan terhadap pedagang kaki lima kepada Walikota Bandar Lampung.

Bagi pedagang kaki lima di kota Bandar Lampung yang tidak memiliki izin melakukan kegiatan usaha diluar lokasi yang ditunjuk oleh Walikota atau Kepala Daerah, akan dikenakan sanksi sebagaimana diatur dalam Pasal 10 Peraturan Daerah Kota Nomor 10 Tahun 1989 tentang Pengaturan dan Pembinaan Pedagang Kaki Lima. Adapun prosedur penerapan sanksi tersebut dilaksanakan dengan cara-cara sebagai berikut:

a. Setiap kegiatan usaha pedagang kaki lima yang tidak memiliki izin diberi peringatan secara tertulis.

b. Peringatan tertulis diberikan sebanyak 3 (tiga) kali berturut-turut dengan tenggang waktu masing-masing 1 (satu) minggu.

c. Peringatan tertulis dikeluarkan oleh Walikota atau pejabat yang ditunjuk.

Sementara Pasal 10 Ayat (2) menyebutkan bahwa apabila yang bersangkutan tidak melaksanakan ketentuan yang berlaku setelah melalui proses peringatan, lokasi pedagang kaki lima dibongkar. Ketentuan inilah yang menjadi dasar bagi Pemerintah Kota Bandar Lampung untuk 
melakukan paksaan pemerintahan (bestuurdwang) berupa pengosongan lokasi yang digunakan oleh pedagang kaki lima untuk berjualan. Hukum tidak akan bisa dipisahkan dari kehidupan suatu masyarakat. Karena di dalam suatu kehidupan masyarakat pasti ada suatu bentuk peraturan yang berlaku di masyarakat tersebut yang berfungsi untuk mengatur tata cara bermasyarakat.

Instansi pelaksana dalam penertiban pedagang kaki lima di Bandar Lampung telah tepat dan sesuai dengan kewenangannya. Lembaga yang ditunjuk untuk melakukan pembongkaran pedagang kaki lima adalah yaitu satuan polisi pamong praja yang mempunyai tugas pokok untuk melaksanakan kewenangan bidang administrasi publik dan politik dalam negeri. Dalam struktur organisasi satuan polisi pamong praja terdapat bidang penegakan. Bidamg penegakan peraturan perundang-undangan mempunyai tugasmelaksanakan sebagian tugas satuan polisi pamong praja di bidang penegakan peraturan perundang-undangan, dan pembinaan Penyidik Pegawai Negeri Sipil (PPNS). Bidang penegakan peraturan perundangundangan ini mempunyai tugas sebagai berikut:

a. Melakukan operasi penegakan peraturan daerah dan perundangundangan;

b. Melakukan Pemeriksaan cepat/singkat;

c. Melakukan penyidikan dan penindakan;

d. Melakukan operasi penegakan peraturan daerah yang bersifat pembinaan/non yustisial;

e. Melakukan koordinasi dengan polri dalam pelaksanaan tugas Penyidik Pegawai Negeri Sipil (PPNS);

f. Melakukan tugas lain yang diberikan oleh atasan.

\section{Faktor-Faktor yang Menghambat Terjadinya Penegakan Hukum Peraturan Daerah Tentang Pengaturan Dan Pembinaan Pedagang Kaki Lima Di Bandar Lampung}

Hasil wawancara dengan Cik Raden, Kepala kantor pada satuan polisi pamong praja Kota Bandar Lampung dengan menjalankan tugasnya, dalam rangka pembinaan dan penegakan hukum, polisi pamong praja Kota Bandar Lampung diharapkan selalu menampilkan performa professional, khususnya dalam menghadapi perkembangan pedagang kaki lima di Bandar Lampung. Maka dari itu, segenap aparat polisi pamong praja Kota Bandar Lampung diharapkan menjadi aparat yang handal dan mempunyai kemampuan pemikiran yang jernih, serta kesehatan dan kemampuan fisik yang prima untuk menunjang keberhasilan dalam tugas-tugas dilapangan. Namun yang lebih penting lagi tentunya setiap aparat satuan polisi pamong praja harus berupaya menempatkan fungsi pembinaan masyarakat khusus lagi pedagang 
kaki lima dibandingkan dengan penegakan hukum. Hal ini penting sebagai usaha preventif agar masyarakat sadar hukum (Perda) dan paham akan pentingnya ketentraman dan ketertiban umum, mengingat ada kecenderungan ketika penegakan hukum lebih ditonjolkan, potensial bagi terjadi konflik.

Penerapan hukum selama ini terkesan tidak konsisten, tidak merata dan tidak kontinu. Peraturan sudah setumpuk, tetapi sistimatika penerapannya belum diatur dengan baik. Kasihan banyak Korban gusuran, pembongkaran karena penerapan hukum yang tidak konsisten. Embrio pedagang kaki lima dibiarkan menjadi besar, ada yang dibangun semi permanen, dipungut retribusi, dimintai sumbangan ini, sumbangan itu, akhirnya tetap digusur, satu-satunya sumber mata pencarian lenyap begitu saja.

Pedagang kaki lima sekecil apapun, termasuk pedagang asongan. Inilah cikal bakal terjadinya pertumbuhan pedagang kaki lima seperti jamur, dimana-mana, dari kota besar sampai kota kecil. Sebenarnya gampang sekali, kalau petugas patroli ini digiatkan, langsung tindak, sehingga kerugian tidak besar. Langkah ini juga akan mendidik masyarakat tertib hukum, taat hukum. Pantau petugas patroli, kalau ada yang kerjanya tidak bagus termasuk terima pungli, langsung ganti atau pecat. Ini langka kedua mendidik penegak hukum taat hukum dan tertib hukum. Kalau ini dijalankan, dijamin tidak akan pernah lagi kita melihat pedagang kaki lima.

Polisi pamong praja dalam melaksanakan tugas penegakan peraturan daerah mempunyai hambatan. Hambatan-hambatan tersebut adalah:

a. Kelembagaan: Meskipun sudah ada program kerja tahunan tentang rencana operasional pembinaan dan penegakan peraturan daerah terhadap pedagang kaki lima dan Keputusan Kepala Daerah, namun pada pelaksanaan masyarakat di daerah cenderung tidak taat pada peraturan yang berlaku.

b. Sumber Daya Manusia: Adanya tuntutan masyarakat terhadap kecepatan pelayanan oleh aparat, namun kemampuan dan keterampilan teknis operasi terhadap pedagang kaki lima kurang memadai.

c. Jaringan Kerja: Kurangnya kerjasama dengan instansi terkait dalam rangka penegakan peraturan daerah terhadap pedagang kaki lima dan kurangnya peraturan yang mendasari tentang koordinasi polisi pamong praja dengan instansi lainnya.

d. Lingkungan yang belum kondusif : Sarana dan prasarana pendukung teknis operasional pembinaan ketentraman dan ketertiban serta penegakan peraturan daerah terhadap pedagang kaki lima masih kurang. Di sisi lain terjadi penurunan tingkat kesadaran dan ketaatan masyarakat terhadap peraturan yang berlaku mengenai pedagang kaki lima. 
Pemerintah daerah berhak menetapkan peraturan daerah dan peraturan-peraturan lain untuk melaksanakan otonomi dan tugas pembantuan. Susunan dan tata cara penyelenggarakan pemerintahan daerah diatur dalam undang-undang. Di dalam ketentuan UU No. 23 Tahun 2014 tentang Pemerintahan Daerah ini dinyatakan bahwa Pemerintah Daerah menyelenggarakan urusan yang menjadi kewenangannya, yaitu menyelenggarakan ketertiban umum dan ketenteraman masyarakat, dimana pelaksanaannya dilakukan oleh Satuan Polisi Pamong Praja (Satpol PP), kecuali:

a. Politik luar negeri

b. Pertahanan

c. Keamanan

d. Yustisi

e. Moneter dan Fiskal Nasional

f. Agama.

Undang-undang No. 23 Tahun 2014 Pasal 149 pada ayat (1) disebutkan bahwa Anggota Satuan Polisi Pamong Praja dapat diangkat sebagai Penyidik Pegawai Negeri Sipil (PPNS). Hal ini menunjukkan bahwa keberadaan Satpol PP sesuai dengan UU No. 23 Tahun 2014 menjadi harus seirama dengan yang diatur pada Undang-undang No. 2 Tahun 2002 tentang Kepolisian Negara RI, serta Undang-undang No. 8 Tahun 1981 tentang Kitab Undang-undang Hukum Acara Pidana. Dalam dua Undang-undang tersebut ditegaskan bahwa penyidik selain Polisi adalah juga Penyidik Pegawai negeri Sipil. Ini artinya bahwa dalam rangka penyidikan terhadap pelanggaran atas ketentuan Perda. Satpol PP yang sudah diangkat sebagai PPNS bisa melakukan aktivitas menjalankan hukum negara.

\section{Penutup}

\section{Simpulan}

Upaya yang dilakukan Polisi Pamong Praja dalam mengatasi hambatan pada saat mengatur ketertiban umum PKL, sejauh ini pemerintah daerah telah melakukan upaya sosialisasi Peraturan Daerah terhadap PKL, sosialisasi ini dilakukan terhadap perwakilan para PKL disetiap titik, agar setelah diberikan sosialisasi yang menjadi perwakilan para PKL tersebut menjelaskan kepada sesama pedagang yang lainnya.

Hambatan eksternal dalam menegakkan Peraturan Daerah tersebut dikarenakan bahwa adanya ketidakserasian pemikiran antara pedagang kaki lima dengan satuan polisi pamong praja. Pedagang kaki lima beranggapan bahwa dengan diberlakukannya Peraturan Daerah tersebut keberadaan mereka semakin terancam, sedangkan di lain pihak pemenuhan kebutuhan hidup tidak bisa ditunda. Sehingga hal ini mendorong mereka untuk tetap 
nekad berjualan di kawasan yang dilarang. Menurut mereka meskipun pemerintah telah memberikan solusi bagi mereka dengan lokasi sebagai tempat relokasi para pedagang kaki lima, namun ditolak dengan alasan sepi. Sedangkan hambatan internal yang dialami oleh satuan polisi pamong praja dalam menegakkan Peraturan Daerah tidak terlepas adanya oknum yang mengejar kepentingan pribadi. Jika masih ada oknum yang melakukan perbuatan tersebut sudah pasti penegakkan Peraturan Daerah untuk kawasan Kota Bandar Lampung tidak akan bisa berjalan lancar. Selain itu masalah yang menghambat penegakkan Peraturan Daerah adalah dengan adanya pungutan liar.

\section{Saran}

Saran-saran dalam penelitian ini adalah sebagai berikut:

a. Agar pelaksanaan kebijakan tersebut dapat berjalan dengan baik maka pemerintah harus memperhatikan beberapa hal diantaranya adalah bentuk dan isi kebijakan tersebut dengan dibuatnya peraturan daerah tersebut diharapkan Bandar Lampung menjadi kota yang indah, bersih dan tertib selainitu satuan polisi pamong praja sebagai pelaksana teknis harus bisa menerapkan peraturan daerah tersebut di masyarakat tanpa melakukan tindakan represif.

b. Kemampuan suatu organisasi dalam membuat kebijakan adalah sangat besar, sebagai suatu lembaga pemerintah dan demi menciptakan suasana kota yang tertib pemerintah daerah harus bisa mempelajari konddisi masyarakat.Pengaruh lingkungan memiliki peran yang sangat kuat jika masyarakat menolak dengan pemberlakuan Peraturan Daerah tersebut sudah pasti masyarakat tidak akan taat pada peraturan daerah tersebut sehingga menimbulkan ketidak tertiban.

\section{Daftar Pustaka}

\section{A. Buku}

Handoyo, B.Restu Cipto. (2003). Hukum Tata Negara, Kewarganegaraan dan Hak Asasi Manusia (Memahami Proses Konsolidasi Sistem Demokrasi di Indonesia). Yogyakarta: Universitas Atma Jaya.

HR, Ridwan. (2006). Hukum Administrasi Negara. Jakarta: PT Raja Grafindo Persada.

Iwanto, Sutrisni. (2001). Kiat Sukses Berwiraswasta, Strategi Baru Mengelola Usaha Kecil dan Menengah. Jakarta: PT. Grasindo Gramedia Edia Sarana.

Marbun, S.F. (1997). Peradilan Administrasi Negara dan Upaya Administratif di Indonesia. Edisi Pertama, Yogyakarta: Liberty. 
Muchsan. (1992). Beberapa Catatan tentang Hukum Administrasi Negara dan Peradilan Administrasi Negara di Indonesia. Yogyakarta: Liberty.

Pandue, Marthias Dusky. (2010). Jernih Melihat Cermat Mencatat, Antologi Karya Jurnalistik Wartawan Senior Kompas. Jakarta: PT. Kompas Media Sarana.

Pasaribu, Iqbal Tawakkal. (2006). Melihat Fenomena Pedagang Kaki Lima Melalui Aspek Hukum. Bandung: Universitas Islam Bandung.

Pudyatmoko, Y. Sri dan Tjandra, W. Ridwan. (1996). Peradilan Tata Usaha Negara Sebagai Salah Satu Fungsi Kontrol Pemerintah. Yogyakarta: Universitas Atmajaya.

Rahardjo, Satjipto. (2009), Masalah Penegakkan Hukum Dalam Suatu Tinjauan Sosiologis. Sinar Baru, Bandung.

Rasyid, Ryas. (2007). Desentralisasi dan otonomi Daerah, Latar Belakang dan masa Depannya. Jakarta: Penerbit LIPI Press.

Utrecht, E. (1985). Pengantar Hukum Administrasi Negara Indonesia. Cetakan Kedelapan, Jakarta: Balai Buku Ichtiar.

\section{B. Majalah}

Manan, Bagir. (1996 ). "Bentuk -Bentuk Perbuatan Keperdataan Yang Dapat Dilakukan Oleh Pemerintah Daerah No. 3 Vol. 14", Majalah Ilmiah Universitas Padjajaran. 3(14).

\section{Peraturan Perundang-Undangan}

Praturan Daerah (Perda) Kota Bandar Lampung Nomor 08 Tahun 2000 Tentang Pembinaan Umum, Ketertiban, Keamanan, Kebersihan, Kesehatan dan Keapikan Dalam Wilayah Kota Bandar Lampung.

Peraturan Walikota Bandar Lampung Nomor 15 Tahun 2013 tentang Tugas, Fungsi, dan Tata Kerja Satuan Polisi Pamong Praja Daerah Kota Bandar Lampung. 
